\title{
ヘモグロビンのアロステリック制御に関するデータ科学的研究 -四次構造変化に対する塩素イオンの役割一
}

田中 美帆 ${ }^{\mathrm{a}}$, 高橋 由芽 ${ }^{\mathrm{a}}$, 高見 慧 ${ }^{\mathrm{a}}$, 北村 勇吉 ${ }^{\mathrm{a}, \mathrm{b}^{*}}$, 長岡 正隆 ${ }^{\mathrm{a}, \mathrm{c}^{\dagger}}$

a 名古屋大学大学院情報学研究科複雑系科学専攻 $\overline{7} 464-8601$ 愛知県名古屋市千種区不老町 A4-3

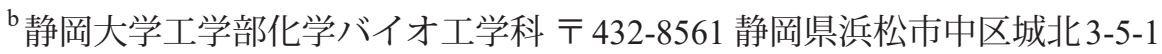

c 名古屋大学価值創造研究センター $=$ 464-8601 愛知県名古屋市千種区不老町 A4-3

*kitamura.yuhkichi@shizuoka.ac.jp †mnagaoka@i.nagoya-u.ac.jp

(Received: August 8, 2021; Accepted for publication: September 16, 2021; Online publication: November 30, 2021)

In this letter, we investigated the contribution of bridging hydrogen bonds (BHB) via $\mathrm{Cl}^{-}$on the T-R transition of human adult hemoglobin ( $\mathrm{HbA}$ ). We applied the time-series clustering method to time-series data of the $\alpha \beta$ dimer rotation angle $\varphi$ and the total number of the BHBs. Compared with the above two results, we have concluded that $\mathrm{Cl}^{-}$ -BHBs do not significantly contribute to the structural regulation of $\mathrm{HbA}$.

Keyword: Hemoglobin, Allostery regulation, Chloride ion, Bridging hydrogen bond, Time-series clustering method

\section{1 はじめに}

ヒト成人へモグロビン $(\mathrm{HbA})(\alpha 2 \beta 2$ グロビン鎖四量体 $)$ は，酸素 $\left(\mathrm{O}_{2}\right)$ や血中に共存するエフェクター分子の濃 度に依存して酸素運搬機能が調節されている [1-3]. X 線構造解析 [1] らら, $\mathrm{HbA}$ の立体構造には $\mathrm{O}_{2}$ 結合親和 性の異なる 2 状態 ( $\mathrm{T}$ 状態と R 状態)が存在することが分 かっており, 一般的には, へムへの酸素分子結合を引 き金とした T-R二状態間遷移によって制御されるという "部位特異的"アロステリック制御機構で説明されてい る $[1,3]$. 近年, 分子動力学 $(\mathrm{MD})$ シミュレーションを用 いた理論研究 $[4,5]$ のデータに, (1)時系列クラスタリン グ法を適用することで, T-R遷移をしたトラジェクトリ (以後 TrajT-R と表記)を自動的に特定することが可能とな り [5], (2) 溶存 $\mathrm{O}_{2}$ の $\mathrm{Hb}$ 内部への進入自体が誘発する立 体構造変化に基づく $\mathrm{T}-\mathrm{R}$ 遷移の分子機構("非部位特異的 "アロステリック制御機構 $[4,5])$ が明らかになってきた. 一方, $\mathrm{O}_{2}$ とは逆の寄与をするネガティブエフェクター である塩素イオン $\left(\mathrm{Cl}^{-}\right)$については, それを含む結晶構 造が得られておらず詳細な機構は明らかとなっていない [2,3]. これまで, $\mathrm{Cl}^{-}$のアロステリック制御機構として, サブユニット間の架橋水素結合(Bridging Hydrogen Bond, BHB)形成(Figure 1) [1] や中央空洞を形成する残基におけ る $\mathrm{Cl}^{-}$イオンによる T状態安定化 [2] などが議論されてき

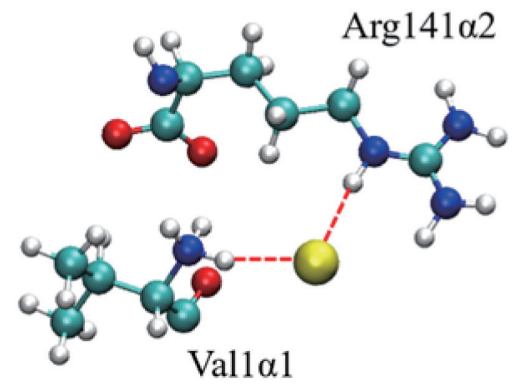

Figure 1. Snapshot of BHB with inter-subunit residues and $\mathrm{Cl}^{-}[1]$.

たが，本研究では，BHB形成に焦点を当てて，HbAの 構造制御に果たす役割を調査した。

\section{2 方法}

\section{1 モデル系と計算概要}

$\mathrm{T}$ 状態 HbAの結晶構造(PDB ID:2DN2 [6])を初期構造 とし, 酸素あり"(+) $\mathrm{O}_{2} "$ ・酸素なし"(-) $\mathrm{O}_{2} "$ ，および3種 類の $\mathrm{Cl}^{-}$濃度条件 $(5,140,1000 \mathrm{mM})$ から, 計6つのモデ ル系を作成した(Table 1). 溶媒には, TIP3P水溶媒モデ ルを用い, シミュレーションボックスには, 直方体モデ ルを採用した. その後, イオン $\left(\mathrm{K}^{+}\right.$または $\left.\mathrm{Cl}^{-}\right)$の初期原 
Table 1. T-R transition ratios under different $\mathrm{Cl}^{-}$and $\mathrm{O}_{2}$ concentrations. It was determined from the time-series data of the rotation angle $\varphi$ defined by $\alpha \beta$ dimers.

\begin{tabular}{lcr}
\hline \multirow{2}{*}{ System } & \multicolumn{2}{c}{$\mathrm{T} \rightarrow \mathrm{R}$ transition ratio } \\
\cline { 2 - 3 } & $(+) \mathrm{O}_{2}$ & $(-) \mathrm{O}_{2}$ \\
\hline $5 \mathrm{mM}$ & $89.7 \%$ & $46.7 \%$ \\
$140 \mathrm{mM}$ & $36.7 \%$ & $23.3 \%$ \\
$1000 \mathrm{mM}$ & $30.0 \%$ & $3.3 \%$ \\
\hline
\end{tabular}

子座標を 30 回ランダム化し, 各系でイオンの初期位置 が異なる独立した 30 個の初期原子座標を得た. さらに, $\mathrm{HbA}$ の構造を固定した状態で平衡化を行った後, 拘束 なし条件の100nsのMDシミュレーションを計180本実 行した(合計 $18 \mu \mathrm{s}$ ). これらのMDシミュレーションは, AMBER 16 [7]の GPU高速版のpmemdにより実行され た.

\section{$2.2 \mathrm{Cl}^{-}$-架橋水素結合}

異なるサブユニットの残基間を $\mathrm{Cl}^{-}$が架橋する水素結 合を, 架橋水素結合 (BHB) と同定し, トラジェクトリ解 析プログラム cpptrajを用いて, $r(\mathrm{~N} \cdots \mathrm{Cl})<4 \AA$ かつ $135^{\circ}$ $<\theta(\mathrm{N}-\mathrm{H}-\mathrm{Cl})<180^{\circ}$ のカットオフ条件に基づき定義した. ただし, サブユニット内で形成される水素結合は含め ずに，全6 $\left(=_{4} \mathrm{C}_{2}\right)$ パターンのサブユニット界面における BHB数をそれぞれ求め, それらの総和(BHB総数)を時 系列解析に用いた。

\section{3 時系列クラスタリング法}

これまで, T状態とR状態を定義するパラメータとし て $\alpha \beta$ 二量体間の回転角(Dihedral Angle, DA) $\varphi$ がよく用い

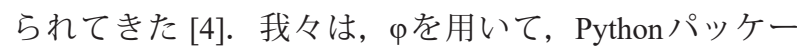
ジTslearn [8]に実装された時系列クラスタリング法SoftDTW法を応用したTrajT-R自動判別法を開発してきた [5]. 本研究では, T-R 遷移に対する $\mathrm{Cl}^{-}-\mathrm{BHB}$ の寄与を調 べるために，HbAのサブユニット界面で形成された BHB 総数の時系列データに対しても時系列クラスタリング法 を適用した．このとき, 各スナップショットで算出され た BHB総数を，1nsごとに区間平均した計 100 点のデー タを, 時系列データとして用いた. 回転角 $\varphi$ とBHB総数 のそれぞれの特徴量に基づき，トラジェクトリを二種類 のクラスタに分類した.

T-R遷移と架橋水素結合 (BHB) との相関を調べるため に，それぞれに基づいたトラジェクトリのクラスタリ ング結果を比較した．二量体回転角 $\varphi$ に基づいたクラス タリングによってクラスタ $X(X=\mathrm{R}$ あるいは $\mathrm{T})$ に分類さ れたトラジェクトリの集合をDAx と表し，BHB総数に

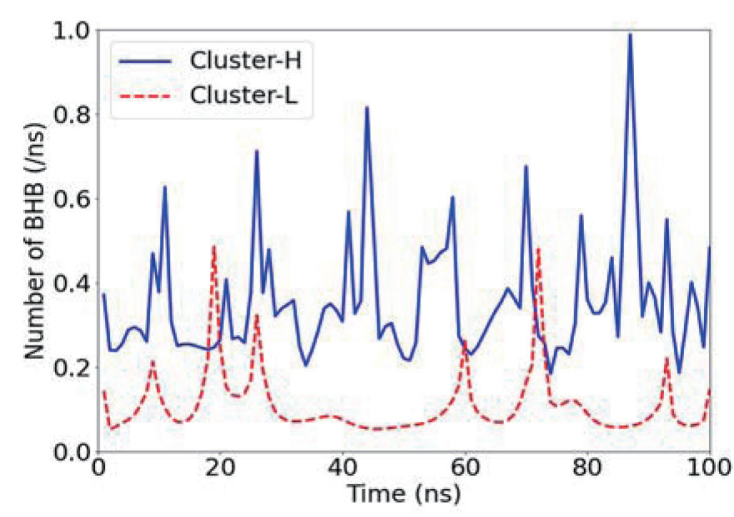

Figure 2. Time dependence of the number of BHBs. Cluster-L and Cluster-H classified by time-series clustering based on the number of BHBs. The centroids of these clusters are shown by red lines for Cluster-L and blue lines for Cluster-H.

基づいたクラスタリングによってクラスタ $Y(Y=\mathrm{L}$ あい はH)に分類されたトラジェクトリの集合を $\mathrm{HB}_{Y}$ と表す (記号 R, T, L, Hについては「3. 結果と考察」を参照)。全 トラジェクトリのうち，XとYに同時に分類されたトラ ジェクトリの割合 $P\left(\mathrm{DA}_{x} \cap \mathrm{HB}_{Y}\right)$ を

$$
P\left(\mathrm{DA}_{x} \cap \mathrm{HB}_{Y}\right)=\frac{n\left(\mathrm{DA}_{x} \cap \mathrm{HB}_{Y}\right)}{n_{\text {tot }}} \times 100(\%)
$$

と定義した. ここで, $n\left(\mathrm{DA}_{x} \cap \mathrm{HB}_{Y}\right)$ は積集合の要素数, $n_{\text {tot }}$ は全トラジェクトリ数を示す. さらに, T-R 遷移と $\mathrm{BHB}$ の相関の度合を示す指標 $R_{X Y}$ を

$$
R_{X Y}=\frac{P\left(\mathrm{DA}_{X} \cap \mathrm{HB}_{Y}\right)-50}{50}
$$

と定義した， $R_{X Y}$ は-1 から 1 の值をとり，1に近いほど $X$ と $Y$ の間に高い相関性を有することを意味する.

\section{3 結果と考察}

Table 1 に，異なる $\mathrm{Cl}^{-}$濃度条件での TrajT-R の割合をま とめた。この結果は $\mathrm{Cl}^{-}$濃度上昇に伴って T-R 遷移が抑 制されるという実験結果 [1-3]を再現しており, 今回の モデル系が $\mathrm{Cl}^{-}$の T-R 遷移制御を調查する上で妥当であ ることを示す。

次に, BHB 総数に基づいた時系列クラスタリングの 結果, 平均的に BHB 総数が異なる 2 種類のクラスタ $\mathrm{HB}_{Y}$ に分類された(Figure 2). BHB総数が少ないクラスタを "Cluster-L"(Figure 2 破線赤), BHB 総数が多いクラスタを "Cluster-H"(Figure 2 実線黒) と命名した。 各クラスタの 
Table 2. Correspondence between two time-series clustering results of T-R transitions $\left(\mathrm{DA}_{X}\right)$ and BHBs $\left(\mathrm{HB}_{Y}\right)$ in the model system of $140 \mathrm{mM} .(+) \mathrm{O}_{2}$. Shading indicates the trajectory was classified as Cluster-R and Cluster-L at the same time

\begin{tabular}{|c|c|c|c|c|c|c|c|c|c|c|c|c|c|c|c|c|c|c|c|c|c|c|c|c|c|c|c|c|c|c|}
\hline $140 \mathrm{mM}(+) \mathrm{O}_{2}$ & & & & & & & & & & & & & & & & & & & & & & & & & & & & & & \\
\hline No. of Trajectory & 1 & 2 & 3 & 4 & 5 & 6 & 7 & 8 & 9 & 10 & 11 & 12 & 13 & 14 & 15 & 16 & 17 & 18 & 19 & 20 & 21 & 22 & 23 & 24 & $25 \sqrt{2}$ & $2 6 \longdiv { 2 }$ & & 282 & 293 & 30 \\
\hline DAx: Cluster R / T & $\mathrm{T}$ & $\mathrm{R}$ & $\mathrm{R}$ & $\mathrm{T}$ & $\mathrm{T}$ & $\mathrm{R}$ & $\mathrm{T}$ & $\mathrm{T}$ & $\mathrm{R}$ & $\mathrm{T}$ & $\mathrm{R}$ & $\mathrm{T}$ & $\mathrm{T}$ & $\mathrm{T}$ & $\mathrm{R}$ & $\mathrm{R}$ & $\mathrm{T}$ & $\mathrm{T}$ & $\mathrm{T}$ & $\mathrm{T}$ & $\mathrm{T}$ & $\mathrm{R}$ & $\mathrm{T}$ & $\mathrm{R}$ & $\mathrm{R}$ & $\mathrm{T}$ & $\mathrm{T}$ & $\mathrm{T} \mid \mathrm{F}$ & $\mathrm{R}$ & $\mathrm{T}$ \\
\hline $\mathrm{HB}_{Y}$ : Cluster L / H & $\mathrm{L}$ & $\mathrm{L}$ & L & $\mathrm{L}$ & $\mathrm{L}$ & $\mathrm{L}$ & $\mathrm{L}$ & L & L & $\mathrm{L}$ & $\mathrm{L}$ & $\mathrm{L}$ & $\mathrm{L}$ & $\mathrm{L}$ & L & $\mathrm{L}$ & $\mathrm{L}$ & $\mathrm{L}$ & $\mathrm{L}$ & L & $\mathrm{L}$ & L & $\mathrm{L}$ & $\mathrm{L}$ & $\mathrm{H}$ & $\mathrm{L}$ & $\mathrm{L}$ & $\mathrm{H}$ & L & $\mathrm{L}$ \\
\hline
\end{tabular}

平均BHB総数は, Cluster-L では $0.109 \mathrm{~ns}^{-1}$ であったのに 対し, Cluster-Hでは $0.354 \mathrm{~ns}^{-1}$ となり, Cluster-Lに比べ て約 3 倍程度多くの水素結合が形成していた。

BHBがT-R遷移のアロステリック制御に関与している と仮定すると, Cluster-Rに分類されたトラジェクトリの 多くはCluster-Lに分類されると推測される. Table 2 に は, $140 \mathrm{mM}(+)_{2}$ の系での2つの時系列クラスタリング 結果の対応表を示しており, 二量体回転角 $\varphi$ に基づいて 分類された $\mathrm{DA}_{X}$ のうち, TrajT-R として分類されたクラス タをCluster-R, T状態が保持されたトラジェクトリとし て分類されたクラスタをCluster-Tと示した. Table 2の網 掛けで示したように, Cluster-Rと Cluster-Lに同時に分類 されたトラジェクトリ数は 10 本であり, 全トラジェク トリ 30 本に対する割合 $P\left(\mathrm{DA} \cap \mathrm{HB}_{\mathrm{L}}\right)$ は $33 \%$, それに対応 する相関度合の指標 $R_{\mathrm{RL}}$ は- 0.33 となる. さらに, 全系 における $P\left(\mathrm{DA} \cap \mathrm{HB}_{\mathrm{L}}\right)$ と $R_{\mathrm{RL}}$ も $57.5 \%$ と 0.15 であり, $\mathrm{T}-\mathrm{R}$ 遷移と BHB総数との間には明確な相関関係は見られな い. したがって, BHBによる T-R遷移制御への寄与は小 さいことが推定され, $\mathrm{Cl}^{-}$-BHB とは異なる機構によって T-R遷移は制御されていると結論づけられる.

\section{4 まとめ}

本研究では, $\mathrm{Cl}^{-}$と $\mathrm{HbA}$ 残基間に形成される架橋水素

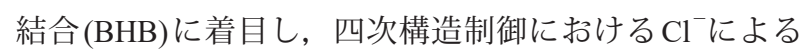
アロステリック機構を検討した. $\alpha \beta$ 二量体回転角 $\varphi$ と BHB総数を用いて時系列クラスタリング解析を行った。 その結果， $\varphi$ に基づいた解析では, $\mathrm{Cl}^{-}$濃度の上昇に伴 い, T-R遷移が抑制される傾向を再現できた。しかしな がら，BHB総数に基づいたクラスタリング結果との比較 からは, 明確な相関関係が見られず, $\mathrm{Cl}^{-}-\mathrm{BHB}$ の形成は, T-R遷移の抑制に対して重要な寄与をしないと結論づけ られる.

今回の結果から, $\mathrm{Cl}^{-}$の直接的な水素結合は $\mathrm{HbA}$ の構 造制御に大きな寄与をしておらず，他の要因(例えば"間 接的"水素結合形成の影響) が支配的であることが示唆
された. 現在, 我々は T-R遷移前後でのサブユニット界 面の水分子を含む水素結合ネットワークに与える $\mathrm{Cl}^{-}$の

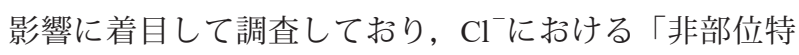
異的」制御機構を明らかにできると期待している.

\section{謝辞}

本研究の一部は, 国立研究開発法人科学技術振興機構 (JST) 戦略的創造研究推進事業(CREST), 文部科学省 科 学研究費補助金事業, 文部科学省「富岳」成果創出加速 プログラム「富岳電池課題」の支援を受けて行われた. また, 計算の一部は, 名古屋大学 情報基盤センターお よび分子科学研究所 計算科学研究センターの計算機を 用いて実施した。

\section{References}

[1] J. F. Storz, (2019). "HEMOGLOBIN: Insights into Protein Structure, Function, and Evolution", Oxford, Oxford University Press. ISBN; 978-0-19-881068-1.

[2] H. Ueno, A. M. Popowicz, J. M. Manning, J. Protein Chem., 12, 561 (1993). DOI:10.1007/BF01025120, PMID:8141998

[3] M. F. Perutz, G. Fermi, C. Poyart, J. Pagnier, J. Kister, J. Mol. Biol., 233, 536 (1993). DOI:10.1006/ jmbi.1993.1530, PMID:8411160

[4] M. Tanakayagi, I. Kurisaki, M. Nagaoka, Sci. Rep., 4, 4601 (2014). DOI:10.1038/srep04601, PMID:24710521

[5] K. Takami, Y. Kitamura, M. Nagaoka, J. Comput. Chem. Jpn., 19, 154 (2020). DOI:10.2477/jccj.2021-0014

[6] S. Y. Park, T. Yokoyama, N. Shibayama, Y. Shiro, J. R. H. Tame, J. Mol. Biol., 360, 690 (2006). DOI:10.1016/j. jmb.2006.05.036 , PMID:16765986

[7] D. A. Case, R. M. Betz, D. S. Cerutti, T. E. Cheatham, III, T. A. Darden, R. E. Duke, et al., (2016), AMBER 2016, University of California, San Francisco.

[8] R. Tavenard, J. Faouzi, G. Vandewiele, F. Divo, G. Androz, C. Holtz, et al., J. Mach. Learn. Res., 21, 1 (2020). 